\title{
Management of childhood croup
}

\author{
William B G Macdonald, Gary C Geelhoed
}

Croup (laryngotracheobronchitis) is a common childhood illness with a peak incidence of 60 per 1000 child-years in those aged between one and two years. ${ }^{1}$ More severe cases of croup are traditionally observed in hospital in order to manage potentially life threatening airway obstruction. Prior to the introduction of steroid therapy, intubation was required in approximately $2 \%$ of these hospitalised children. ${ }^{2-4}$

When a previously well child presents with hoarseness, barking cough and stridor, a diagnosis of croup is relatively straightforward. Children with a longstanding history of stridor or those under four months of age should be carefully evaluated for anatomical airway obstruction, such as laryngeal cyst or papillomatosis, vocal cord paresis, extrinsic airway compression (e.g. vascular ring), or laryngotracheal stenosis. In children with high fevers and/or a toxic appearance, consideration should be given to more serious infections such as bacterial tracheitis, retropharyngeal abscess, or epiglottitis. However, routine immunisation against Haemophilus influenzae type b has dramatically reduced the incidence of invasive $H$ influenzae type $b$ infection, so that epiglottitis is now a rare diagnosis in completely immunised children. ${ }^{5}$

Croup has traditionally been divided into viral and spasmodic types. In our experience, however, such a distinction is often not possible; approximately $40 \%$ of children admitted to our institution have features to suggest both viral (fever, rhinorrhoea) and spasmodic (atopy, multiple previous episodes) aetiologies and we would concur with Skolnik that the two conditions lie on a single spectrum of illness. ${ }^{6}$

Traditional advice regarding management of croup has included use of antipyretics, maintenance of a reasonable fluid intake, and humidified air - either in the form of warm steam in the home setting or cool mist in hospital, the latter usually delivered through a mist tent or "croupette". Most young children placed in mist tents find the experience frightening and careful observation of the child is rendered more difficult. This advice regarding humidified air originated in an era when many children who died from upper airway obstruction could be shown to have bacterial infection (either primary or secondary) and little other definitive therapy was possible, it being argued that humidification would be useful to loosen airway secretions. In fact, the only randomised trial of humidification in croup ever undertaken failed to show any benefit, although the number of patients in this study was very small. ${ }^{7}$ In an animal model of croup, in which airway oedema was induced by inflicting a mild thermal injury, humidified air was shown to result in greater airway resistance than dry air, while air temperature was shown to have little effect. ${ }^{8}$ Nebulised saline has not been shown to result in any sustained improvement in clinical status when used as a placebo treatment in trials involving nebulised adrenaline or budesonide. ${ }^{910}$ The use of humidified air was abandoned in most Australian children's hospitals more than a decade ago, without any observable deterioration in clinically important parameters such as the proportion of children requiring admission to intensive care or intubation or the length of hospital stay. ${ }^{4}$ There seems little reason to discourage the use of bathroom steam for children with croup in the home setting, particularly as the reduction in anxiety which both child and parent experience may be clinically useful, but it should be recognised that this is almost certainly a placebo effect and there is no evidence to support the continuing use of mist therapy in inpatient environments.

Corticosteroids were first advocated in croup in the 1950 s, but a succession of clinical trials conducted over the ensuing 30 years failed to establish any clear benefit from their use. ${ }^{11-20}$ In 1989 Kairys et al published a metaanalysis of the nine methodologically satisfactory studies to date which had examined the use of steroid therapy in croup and concluded that there was a benefit from its use with a suggestion of a dose-response effect. ${ }^{21} \mathrm{Six}$ placebo controlled studies looking at the effect of steroids in children admitted to hospital with croup have since been published and all have shown a clinically useful benefit, with improvements in clinical parameters,${ }^{102-26}$ duration of hospital stay, ${ }^{102526}$ and requirement for "rescue" medication in the form of nebulised adrenaline. ${ }^{10}$ None of these trials had sufficient statistical power to demonstrate a reduction in the proportion of children who died or required endotracheal intubation, both now comparatively rare outcomes. Steroids have, however, been shown to markedly reduce post-extubation stridor in children with severe croup who required endotracheal intubation. ${ }^{27}$

Various steroid agents and routes of administration have been used in croup, and all have shown a benefit, so clinicians now have a range of therapeutic options from which to choose. Dexamethasone, a fluorinated derivative of prednisolone, has been the most extensively studied drug. Earlier studies employed large doses (e.g. $0.6 \mathrm{mg} /$ $\mathrm{kg}$ ) of parenteral dexamethasone, but more recent work from our own institution has shown that the oral preparation works well and that much smaller doses (e.g. $0.15 \mathrm{mg} / \mathrm{kg}$ ) are as effective as larger doses. ${ }^{28}$ Prednisolone has not been as widely studied but there seems little reason to believe that equivalent doses (e.g. $1 \mathrm{mg} / \mathrm{kg}$ ) would not be useful. These smaller doses are consistent with single steroid doses commonly used in asthma. A single dose is usually adequate for mild to moderate croup and clinical relapse is uncommon once children have improved to a point where they are ready for discharge from hospital, ${ }^{102527-31}$ although the dose can be repeated 12-24 hours later if necessary. Prolonged courses of steroids are unnecessary, except perhaps in children with severe croup who are being managed in intensive care settings.

More recently, nebulised budesonide has been shown to be useful in mild to moderate croup. All studies examining the effect of budesonide have used a fixed dose of $2 \mathrm{mg}$. Although the initial study by Husby et al used two doses, they were able to demonstrate a clinical improvement prior to administration of the second dose. ${ }^{24}$ Several studies have since documented the efficacy of a single dose of budesonide in mild to moderate croup..$^{102-2632}$ Only one study has compared nebulised budesonide with systemic steroids and no significant difference in efficacy was seen between the two treatments. ${ }^{10}$ Another study examined whether nebulised budesonide and systemic steroids were synergistic and showed that budesonide exerted a modest additive effect to oral dexamethasone $(0.6 \mathrm{mg} / \mathrm{kg})$, although 
there was no reduction in admissions to hospital. ${ }^{33} \mathrm{~A}$ recent study which examined the effects of nebulised dexamethasone in large doses in hospitalised children showed a clinical improvement in treated children compared with controls at four hours, but no reduction in the length of time in hospital. ${ }^{34}$

A remarkable feature of many of the trials concerning use of steroids in children with croup has been the rapid onset of a therapeutic effect, irrespective of the route of administration. Most children with croup given steroids show a prompt (within 1-2 hours) and sustained improvement, and it is now our practice to observe children with moderate croup in the emergency department for a couple of hours following steroid administration and to allow them home if there has been an obvious improvement. The rapid onset of action seems unlikely to be on the basis of alterations in protein transcription and it is probable that steroids have some other important effect in croup.

Although steroid administration results in a prompt improvement in clinical status, there is no significant reduction in the duration of symptoms, particularly the viral symptoms of cough, rhinorrhoea, and sore throat which frequently accompany viral croup. ${ }^{1035}$ Nonetheless, both doctors and parents consistently rate steroid treated children as being less unwell than placebo treated controls, and there is less requirement for ongoing medical care following discharge home.

It appears, then, that moderate doses of corticosteroids given by a variety of routes are beneficial in children admitted to hospital with croup. Like asthma, increasing the steroid dose beyond a certain "threshold" level is unlikely to result in additional benefit, and the doses of steroids required in croup are very similar to those used in asthma. We prefer oral dexamethasone which is both cheap and well tolerated by children. It is important to remember that the oral bioavailability of dexamethasone sodium phosphate (the usual parenteral preparation) may be poor and care needs to be taken to ensure that the correct preparation is used. Budesonide is more expensive and requires the presence of a nebuliser. In addition, nebuliser therapy is usually very distressing for young children and is contrary to the philosophy of "minimal handling" in children with upper airway obstruction. The amount of systemically absorbed steroid is bound to be less following a budesonide nebulisation compared with an oral or parenteral dose of dexamethasone, but this is probably of negligible clinical importance for a single dose treatment that is administered only occasionally.

Both oral and parenteral dexamethasone and nebulised budesonide have also been shown to be useful in children with croup too mild to warrant hospital admission. ${ }^{25} 333536$ While steroids did not shorten the duration of illness in these children, there was a significant reduction in symptom severity and in the proportion of children whose parents were concerned enough to return them for medical consultation. $^{35}$ In the absence of more important outcome measures, whether such children ought to be treated with steroids remains a matter of physician and patient preference. We believe that the potential for adverse effects following a single dose of steroid is extremely low and that the clinical improvement seen in steroid-treated children justifies its use, even in outpatient settings.

Nebulised adrenaline has an established place in severe croup. It has been shown to result in rapid clinical improvement, although the effect may last for only 2-3 hours. ${ }^{937-40}$ Initial studies employed racemic mixtures because of fears regarding cardiotoxicity, but a recent trial has shown the L-isomer (the usual form available for resuscitation) to be both safe and effective. ${ }^{41}$ The doses required (e.g. $4 \mathrm{mg}$ ) are substantial and tachycardia and circumoral pallor are usual following administration. The introduction of routine steroid use in our institution has virtually eliminated the need for repeated doses of nebulised adrenaline in children with croup. ${ }^{410}$ It has been traditional to recommend that, in view of its short duration of action, children treated with nebulised adrenaline should all be admitted to hospital for observation. Three recent North American studies have shown that children treated with nebulised adrenaline could safely be discharged home if they were free of symptoms $2-3$ hours later, ${ }^{29-31}$ although it is noteworthy that the children in these studies also received steroids on a routine basis. More recently, an Australian study has shown that nebulised adrenaline alone was as efficacious as nebulised budesonide in children admitted to hospital with croup, ${ }^{32}$ although the results of this study would at least need to be duplicated before adrenaline could be advocated as an alternative monotherapy to steroids for children with croup.

Endotracheal intubation for severe croup is still a life saving measure but is almost never required when effective doses of steroids and adrenaline have been administered. In our institution the only children intubated for croup during the last five years - when steroids have routinely been given to children admitted to hospital with croup have either had pre-existing airway abnormalities or have been intubated in a peripheral facility prior to transfer. ${ }^{4}$ This experience is similar to that of other centres. ${ }^{42}$

It is time to stop the discussion about whether or not steroids are beneficial in children with croup; that issue has been comprehensively resolved. There remain unanswered questions about aspects of dose and route of administration but these seem to be of marginal clinical importance. Nebulised adrenaline is useful in severe cases but is rarely necessary following steroid administration. We advocate routine steroid use in children admitted to hospital with croup, and also believe it should be considered in an outpatient setting.

Emergency Department,

Princess Margaret Hospital for Children, GPO Box D184,

Perth, Western Australia 6001

1 Denny FW, Clyde FW, Clyde WA Jr. Acute lower respiratory tract infections in nonhospitalized children. F Pediatr 1986;108:635-45.

2 Sendi K, Crysdale WS, Yoo J. Tracheitis: outcome of 1700 cases presenting to the emergency department during two years. F Otolaryngol 1992;21: $20-4$.

3 Tan AK, Manoukian JJ. Hospitalized croup (bacterial and viral): the role of rigid endoscopy. $\mathscr{F}$ Otolaryngol 1992;21:48-53.

4 Geelhoed GC. Sixteen years of croup in a Western Australian teaching hospital: the impact of routine steroid therapy. Ann Emerg Med 1996;28: 621-6.

5 Alho OP, Jokinen K, Pirila T, Ho A, Oja H. Acute epiglottitis and infant conjugate Haemophilus influenzae type b vaccination in northern Finland. Arch Otolaryngol Head Neck Surg 1995;121:898-902.

6 Skolnik NS. Treatment of croup. A critical review. Am f Dis Child 1989 143:1045-9.

7 Bourchier D, Dawson KP, Fergusson DM. Humidification in viral croup a controlled trial. Aust Paediatr $\mathcal{F}$ 1984;20:289-91.

8 Wolfsdorf J, Swift DL. An animal model simulating acute infective upper airway obstruction of childhood and its use in the investigation of croup therapy. Pediatr Res 1978;12:1062-5.

9 Westley CR, Cotton EK, Brooks JG. Nebulized racemic epinephrine by IPPB for the treatment of croup. Am $\mathcal{F}$ Dis Child 1978;132:484-7.

10 Geelhoed GC, Macdonald WBG. Oral and inhaled steroids in croup: a randomized, placebo-controlled trial. Pediatr Pulmonol 1995;20:355-61.

11 Martensson B, Nilson G, Torbjar J. The effect of corticosteroids in the treatment of pseudo-croup. Acta Otolaryngol (Stockh) 1960;158(Suppl): $62-9$.

12 Novik A. Corticosteroid treatment of non-diptheritic croup. Acta Otolaryngol (Stockh) 1960;158(Suppl):20-2.

13 Eden A, Larkin VP. Corticosteroid treatment of croup. Pediatrics 1964;33. $768-9$.

14 Sussman S, Grossman M, Magoffin MD, Schieble J. Dexamethasone (16 alpha-methyl, 9 alpha-fluoroprednisolone) in obstructive respiratory tract infections in children. Pediatrics 1964;34:851-5

15 Skowron PN, Turner JAP, McNaughton GA. The use of corticosteroid (dexamethasone) in the treatment of acute laryngotracheitis. Can Med Assoc F 1966;94:528-31.

16 Eden A, Kaufman A, Yu R. Corticosteroid and croup. $\mathcal{F A M A} 1967 ; 200$ 403-4.

17 James JA. Dexamethasone in croup. Am f Dis Child 1969;117:511-6. 
18 Leipzig B, Oski FA, Cummings CW, Stockman JA, Swender P. A prospective randomized study to determine the efficacy of steroids in the treatment of croup. 7 Pediatr 1979;94:194-6.

19 von Mühlendahl KEon, Kahn D, Spohr HL, Dressler F. Steroid treatment in pseudo-croup. Helv Paediatr Acta 1982;37:431-6.

20 Koren G, Frand M, Barzilay Z, MacLeod SM. Corticosteroid treatment of laryngotracheitis v spasmodic croup in children. Am f Dis Child 1983; 137:941-4.

21 Kairys SW, Olmstead EM, O'Connor GT. Steroid treatment of laryngotracheitis: a meta-analysis of the evidence of randomized trials. Pediatrics 1989;83:683-93

22 Kuusela A, Vesikari T. A randomised, double-blind, placebo-controlled trial of dexamethasone and racemic epinephrine in the treatment of croup. Acta Paediatr Scand 1988;77:99-104.

23 Super DM, Cartelli NA, Brooks LJ, Lembo RM, Kumar ML. A prospective randomized double-blind study to evaluate the effect of dexamethasone in acute laryngotracheitis. $\mathcal{7}$ Pediatr 1989;115:323-9.

24 Husby S, Agertoft L, Mortensen S, Pedersen S. Treatment of croup with nebulised steroid (budesonide): a double blind, placebo controlled study. Arch Dis Child 1993;68:352-5.

Arch Dis Child 1993;68:352-5.
25 Klassen TP, Feldman ME, Watters LK, Sutcliffe T, Rowe PC. Nebulized budesonide for children with mild-to moderate croup. $N$ Engl $\mathcal{F}$ Med budesonide for chil

26 Godden CW, Campbell MJ, Hussey M, Cogswell JJ. Double blind placebo controlled trial of nebulised budesonide for croup. Arch Dis Child 1997; controlled

27 Tibballs J, Shann FA, Landau LI. Placebo-controlled trial of prednisolone in children intubated for croup. Lancet 1992;340:745-8.

28 Geelhoed GC, Macdonald WBG. Oral dexamethasone in the treatment of croup: $0.15 \mathrm{mg} / \mathrm{kg}$ versus $0.3 \mathrm{mg} / \mathrm{kg}$ versus $0.6 \mathrm{mg} / \mathrm{kg}$. Pediatr Pulmonol 1995;20:362-8.

29 Kelley PB, Simon JE. Racemic epinephrine use in croup and disposition. Am f Emerg Med 1992;10:181-3.

30 Prendergast M, Jones JS, Hartman D. Racemic epinephrine in the treatment of laryngotracheitis: can we identify children for outpatient therapy ? Am f Emerg Med 1994;12:613-6.
31 Ledwith CA, Shea LM, Mauro RD. Safety and efficacy of nebulized racemic epinephrine in conjunction with oral dexamethasone and mist in the outpatient treatment of croup. Ann Emerg Med 1995;25:331-7.

32 Fitzgerald D, Mellis C, Johnson M, Allen H, Cooper P, Van Asperen P. Nebulized budesonide is as effective as nebulized adrenaline in moderately severe croup. Pediatrics 1996;97:722-5.

33 Klassen TP, Watters LK, Feldman ME, Sutcliffe T, Rowe PC. The effect of nebulized budesonide in dexamethasone-treated outpatients with croup. Pediatrics 1996;97:463-6.

34 Johnson DW, Schuh S, Koren G, Jaffee DM. Outpatient treatment of croup with nebulized dexamethasone. Arch Pediatr Adolesc Med 1996;150: $349-55$.

35 Geelhoed GC, Turner J, Macdonald WBG. Efficacy of a small single dose of oral dexamethasone for outpatient croup: a double blind placebo controlled clinical trial. BMF 1996;313:140-2.

36 Cruz MN, Stewart G, Rosenberg N. Use of dexamethasone in the outpatient management of acute laryngotracheitis. Pediatrics 1995;96:220-3.

37 Gardner HG, Powell KR, Roden VJ, Cherry JD. The evaluation of racemic epinephrine in the treatment of infectious croup. Pediatrics 1973;52:52-5.

38 Taussig LM, Castro O, Beaudry PH, Fox WW, Bureau M. Treatment of laryngotracheobronchitis (croup). Use of intermittent positive-pressure breathing and racemic epinephrine. Am f Dis Child 1975;129:790-3.

39 Fogel JM, Berg IJ, Gerber MA, Shorter CB. Racemic epinephrine in the treatment of croup: nebulization alone versus nebulization with intermittent positive pressure breathing. $\mathcal{F}$ Pediatr 1982;101:1028-31.

40 Kristjansson S, Berg-Kelly K, Winso E. Inhalation of racemic adrenaline in the treatment of mild and moderately severe croup. Clinical symptom score and oxygen saturation measurements for evaluation of treatment score and oxygen saturation measurem

41 Waisman Y, Klein BL, Boenning DA, et al. Prospective randomized doubleblind study comparing L-epinephrine and racemic epinephrine aerosols in the treatment of laryngotracheitis (croup). Pediatrics 1992;89:302-6.

$42 \mathrm{McDonogh}$ AJ. The use of steroids and nebulised adrenaline in the treatmen of viral croup over a seven year period at a district hospital. Anaesth Intensive Care 1994;22:175-8. 